\title{
TINGKAT PENERAPAN SAK EMKM PADA PELAKU UMKM DAN UPAYA PENINGKATAN PENERAPAN SAK EMKM DILIHAT DARI PERSEPSI UMKM DAN SOSIALISASI SAK EMKM
}

\author{
I Gde Agung Wira Pertama, I Nyoman Sutapa* \\ Program Studi Akuntansi Fakultas Ekonomi dan Bisnis, Universitas Warmadewa \\ e-mail: vii6unk@gmail.com
}

\begin{abstract}
Micro, small and medium enterprises are still constrained by the collection of financial statements and if left unchecked it will have a negative impact on development, one of which is that development is low because it increases capital and will make it harder for banks to analyze the feasibility of credit assistance for users. The population in this study was 97.277 in Denpasar district by taking a sample of 100 companies randomly. Based on the results of the data analysis, it can be concluded that H1 was rejected because the Perception of SMEs did not oppose the adoption of SAK EMKM in the city of Denpasar and H2 was accepted because the SAK EMKM socialization was positively beneficial to the application of SAK EMKM in the city of Denpasar.
\end{abstract}

Keywords: Perception, Socialization, Financial Accounting Standards

\section{Abstrak}

Usaha mikro, kecil, dan menengah masih terkendala dengan penyusunan laporan keuangan dan jika dibiarkan hal itu akan berdampak negatif bagi perkembangan, salah satunya adalah produktivitas menjadi rendah karena kurangnya modal dan akan mempersulit perbankan melakukan analisa kelayakan pemberian kredit kepada pelaku. Populasi dalam penelitian ini adalah di kabupaten Denpasar sebanyak 97,277 dengan mengambil sampel sebanyak 100 perusahaan secara acak. Berdasarkan hasil Analisa data maka dapat disimpulkan bahawa H1 ditolak karena Persepsi Pelaku UMKM tidak berpengaruh terhadap Penerapan SAK EMKM di kota Denpasar dan H2 diterima karena Sosialisasi SAK EMKM berpengaruh positif terhadap Penerapan SAK EMKM di kota Denpasar.

Kata Kunci : Persepsi, Sosialisai, Standar Akuntansi Keuangan

\section{PENDAHULUAN}

Kementrian Komunikasi dan Informatika (kemenkominfo) RI menilai keberadaan usaha mikro kecil dan menengah (UMKM) di Bali sangat maju. kemenkominfo menilai kemajuan itu karena masyarakat Bali sangat kreatif dan inovatif sehingga apa saja bisa menjadi karya seni (Suadnyana, 2018). Menurut Badan Pusat Statistik Provinsi bali tercatat jumlah UMKM di Bali yang terbanyak adalah di Kota Denpasar sebanyak 97,277

Asisten Deputi Peningkatan Daya Saing Koperasi UMKM Kementerian Koordinator Bidang Perekonomian Iwan Faidi di Semarang, Kamis (20/4/2017) menyatakan bahwa usaha mikro, kecil, dan menengah (UMKM) masih terkendala dengan penyusunan laporan keuangan dan jika dibiarkan hal itu akan berdampak negatif bagi perkembangan UMKM, salah satunya adalah produktivitas menjadi rendah karena kurangnya modal dan akan mempersulit perbankan melakukan analisa kelayakan pemberian kredit kepada pelaku UMKM (Hidayat, 2017).

Mulai 1 Januari 2018, Ikatan Akuntan Indonesia (IAI) memberlakukan Standar Akuntansi Keuangan (SAK) baru khusus untuk Entitas Mikro Kecil dan Menengah (EMKM). Dengan adanya SAK EMKM maka diharapkan UMKM lebih maju dan mandiri misalnya UMKM dapat menyeleggarakan pencatatan atas laporan keuangan usahanya. Mengingat informasi akuntansi mempunyai peranan penting untuk mencapai keberhasilan usaha, termasuk bagi UMKM. Informasi akuntansi dapat menjadi dasar yang andal untuk memperoleh kredit dari bank, tujuan pelaporan pajak maupun tujuan internal perusahaan seperti pengambilan keputusan ekonomis dalam pengelolaan usaha, antara lain keputusan pengembangan pasar, penetapan harga dan lain-lain. Dengan demikian diharapkan dengan adanya SAK EMKM akan meningkatkan profesionalitas dari UMKM. Dengan adanya SAK EMKM, maka UMKM 
tidak perlu membuat laporan keuangan dengan menggunakan SAK umum berbasis IFRS dan SAK ETAP. Di dalam beberapa hal SAK EMKM memberikan banyak kemudahan bagi UMKM karena SAK EMKM memuat pengaturan akuntansi yang lebih sederhana dibandingkan dengan SAK ETAP.

Mengingat usaha mikro, kecil, dan menengah (UMKM) masih terkendala dengan penyusunan laporan keuangan beberapa peneliti telah melakukan penelitian terkait pemahaman UMKM terhadap SAK EMKM berikut Hasil penelitian Salmiah dkk (2018) yang dilakukan pada kota pekanbaru membuktikan bahwa pelaku UMKM di kota pekan baru belum memiliki pemahaman yang tinggi terhadap SAK EMKM, sedangkan untuk Denpasar peneliti masih belum bisa menemukan penelitian yang menyatakan tingkat pemahaman atau penerapan SAK EMKM pada UMKM di kota Denpasar. Berdasarkan latar belakang tersebut maka peneliti tertarik untuk melakukan penelitian mengenai tingkat penerapan SAK EMKM pada pelaku UMKM dan upaya peningkatan penerapan SAK EMKM dilihat dari persepsi UMKM dan sosialisasi SAK EMKM.

\section{TINJAUAN PUSTAKA}

Sesuai dengan Undang- Undang Nomor 20 Tahun 2008 tentang Usaha Mikro, Kecil dan Menengah (UMKM), Usaha Mikro adalah usaha produktif milik orang perorangan dan/atau badan usaha perorangan yang memenuhi kriteria Usaha Mikro sebagaimana diatur dalam Undang-Undang ini. Usaha Kecil adalah usaha ekonomi produktif yang berdiri sendiri, yang dilakukan oleh orang perorangan atau badan usaha yang bukan merupakan anak perusahaan atau bukan cabang perusahaan yang dimiliki, dikuasai, atau menjadi bagian baik langsung maupun tidak langsung dari usaha menengah atau usaha besar yang memenuhi kriteria Usaha Kecil sebagaimana dimaksud dalam Undang-Undang ini. Usaha Menengah adalah usaha ekonomi produktif yang berdiri sendiri, yang dilakukan oleh orang perseorangan atau badan usaha yang bukan merupakan anak perusahaan atau cabang perusahaan yang dimiliki, dikuasai, atau menjadi bagian baik langsung maupun tidak langsung dengan Usaha Kecil atau usaha besar dengan jumlah kekayaan bersih atau hasil penjualan tahunan sebagaimana diatur dalam Undang-Undang ini. Usaha Menengah adalah usaha ekonomi produktif yang berdiri sendiri, yang dilakukan oleh orang perseorangan atau badan usaha yang bukan merupakan anak perusahaan atau cabang perusahaan yang dimiliki, dikuasai, atau menjadi bagian baik langsung maupun tidak langsung dengan Usaha Kecil atau usaha besar dengan jumlah kekayaan bersih atau hasil penjualan tahunan sebagaimana diatur dalam Undang-Undang ini.

\section{Pengaruh Persepsi Korupsi Pajak Terhadap Kepatuhan Wajib Pajak \\ Persepsi adalah bagaimana cara} seseorang melihat, menggambarkan atau menginterpretasikan sebuah objek, peristiwa, serta manusia. Orang-orang akan berprilaku sesuai dengan persepsi yang mereka miliki (Lubis, 2009). Persepsi pelaku UMKM dapat merubah pemikiran yang semula mengganggap sulit menyusun laporan keuangan menjadi suatu hal yang mudah sehingga pelaku UMKM akan tertib menyusun laporan keuangan yang berbasis SAK EMKM (Janrosl, 2018). Berdasarkan hal tersebut maka peneliti merumuskan hipotesis sebagai berikut.:

$\mathrm{H}_{1}$ : Persepsi pelaku UMKM berpengaruh positif terhadap penerapan SAK EMKM di kota Denpasar.

\section{Pengaruh Kualitas Pelayanan Petugas Pajak Terhadap Kepatuhan Wajib Pajak}

Sosialisasi SAK EMKM merupakan proses individu belajar bagaimana menyesuaikan diri dengan lingkungan tertentu dan bagaimana mengkoordinasikan perilakunya dengan perilaku orang lain dan belajar sesuai dengan peranan dan peraturan yang ditetapkan yakni SAK EMKM. Menurut Shonhadji dan Djuwito (2017) menyatakan bahwa sosialisasi SAK EMKM sangat mendukung pelaku UMKM memahami bagaimana cara penggunaan dan keuntungan menggunakan SAK EMKM Berdasarkan hal tersebut maka peneliti merumuskan hipotesis sebagai berikut. :

$\mathrm{H}_{2}$ : Sosialisasi SAK EMKM berpengaruh positif terhadap penerapan SAK EMKM di kota Denpasar. Berdasarkan uraian sebelumnya, maka rerangka penelitian ini adalah sebagai berikut: 


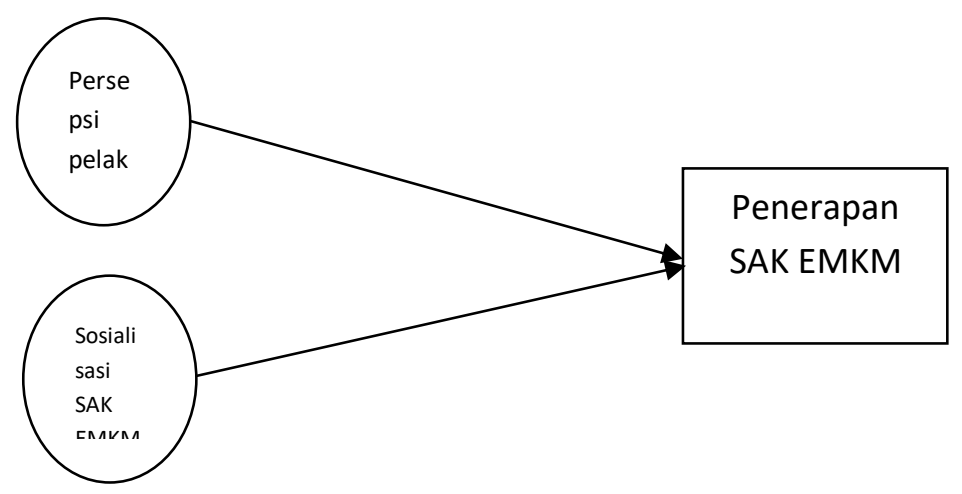

Gambar 1. Rerangka Penelitian

\section{METODE PENELITIAN}

Penelitian ini menggunakan metode analisis statistik deskriptif untuk menggambarkan 1) Penerapan SAK EMKM oleh pelaku UMKM di kota Denpasar. 2) Persepsi Pelaku UMKM di kota Denpasar terhadap SAK EMKM. 3)Menggambarkan sosialisasi SAK EMKM terhadap pelaku UMKM di kota Denpasar. Uji Partial least square (PLS) juga dilakukan dalam penelitian ini untuk menguji pengaruh 1) Persepsi Pelaku UMKM terhadap Penerapan SAK
EMKM di kota Denpasar dan 2) Menguji pengaruh sosialisasi SAK EMKM terhadap Penerapan SAK EMKM di kota Denpasar. Populasi dalam penelitian ini adalah UMKM di kabupaten Denpasar sebanyak 97,277 (Badan pusat statistik Bali 2019) pada penelitian ini menggunakan sampel sebanyak 100 responden yang didapat dengan menggunakan rumus slovin. Definisi operasional dan pengukuran variabel dapat dilihat pada tabel 1

Tabel 1

Definsi Operasional dan Pengukuran Variabel

\begin{tabular}{|c|c|c|c|}
\hline Variabel & Definisi & Referensi & Pengukuran \\
\hline $\begin{array}{l}\text { Penggunaan SAK } \\
\text { EMKM }\end{array}$ & $\begin{array}{l}\text { standar yang diberlakuakan untuk pelaku } \\
\text { usaha mikro kecil dan menengah sebagai } \\
\text { penyerdahaan dari SAK ETAP }\end{array}$ & $\begin{array}{l}\text { (Shonhadji dan } \\
\text { Djuwito, 2017) }\end{array}$ & $\begin{array}{l}\text { Empat item pertanyaan } \\
\text { yang diukur dengan } \\
\text { menggunakan skala } \\
\text { likert lima poin. }\end{array}$ \\
\hline $\begin{array}{l}\text { Persepsi Pelaku } \\
\text { Usaha Mikro Kecil } \\
\text { dan Menengah }\end{array}$ & $\begin{array}{l}\text { Pemikiran pelaku usaha mikro kecil dan } \\
\text { menengah terhap SAK EMKM }\end{array}$ & (Janrosl, 2018) & $\begin{array}{lr}\text { Sepuluh } & \text { item } \\
\text { pertanyaan } & \text { yang } \\
\text { diukur } & \text { dengan } \\
\text { menggunakan } & \text { skala } \\
\text { likert lima poin. } & \\
\end{array}$ \\
\hline $\begin{array}{ll}\text { Sosialisasi } & \text { SAK } \\
\text { EMKM } & \end{array}$ & $\begin{array}{l}\text { Merupakan usaha yang dilakukan dari } \\
\text { IAI dan lembaga lainnya dalam proses } \\
\text { sosialisasi terkait SAK EMKM. }\end{array}$ & $\begin{array}{l}\text { (Badria dan } \\
\text { Diana, 2018) }\end{array}$ & $\begin{array}{l}\text { Empat item pertanyaan } \\
\text { yang diukur dengan } \\
\text { menggunakan skala } \\
\text { likert lima poin. }\end{array}$ \\
\hline
\end{tabular}

\section{HASIL PENELITIAN DAN PEMBAHASAN \\ Penerapan SAK EMKM pada UMKM di kota Denpasar \\ Berdasarkan hasil tabulasi yang didapat} melalui kuesioner yang terdiri dari 4 item pernyataan dapat disimpulkan bahwa penerapan SAK EMKM pada UMKM di kota Denpasar sudah menerapkan SAK EMKM. Hal ini dibuktikan dengan jawaban kuesioner pada jawaban setuju hingga sangat setuju yang dimana jawaban tersebut mengacu kepada indikator penerapan SAK EMKM pada UMKM. Berikut disajikan diagram untuk melihat hasil persentase jawaban para responden yang berjumlah 100 responden. Terlihat pada gambar 2, responden sebagian besar menjawab sangat setuju (SS) sebanyak $22 \%$, dan setuju (S) $63 \%$ 


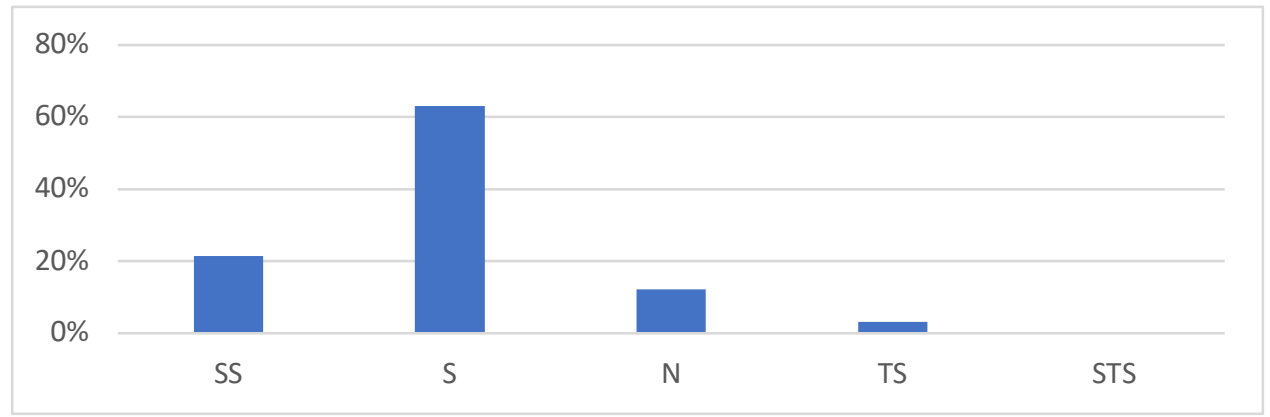

Gambar 2 Gambaran jawaban responden atas Penerapan SAK EMKM pada UMKM di kota Denpasar

Sumber : Data diolah 2019

\section{Persepsi Pelaku UMKM di kota Denpasar terhadap SAK EMKM}

Berdasarkan hasil tabulasi yang didapat melalui kuesioner yang terdiri dari 10 item peryataan dapat disimpulkan bahwa persepsi pelaku UMKM di kota denpasar terhadap SAK EMKM sebagian besar memiliki persepsi yang baik terhadap SAK EMKM, hal ini dibuktikan dengan jawaban kuesioner pada jawaban setuju hingga sangat setuju yang dimana jawaban tersebut mengacu kepada indikator persepsi pelaku UMKM terhadap SAK EMKM. Berikut disajikan diagram untuk melihat hasil persentase jawaban para responden yang berjumlah 100 responden sesuai dengan pengambilan sampel pada gambar 3 Responden sebagian besar menjawab sangat setuju (SS) sebanyak 39\%, dan setuju (S) $56 \%$

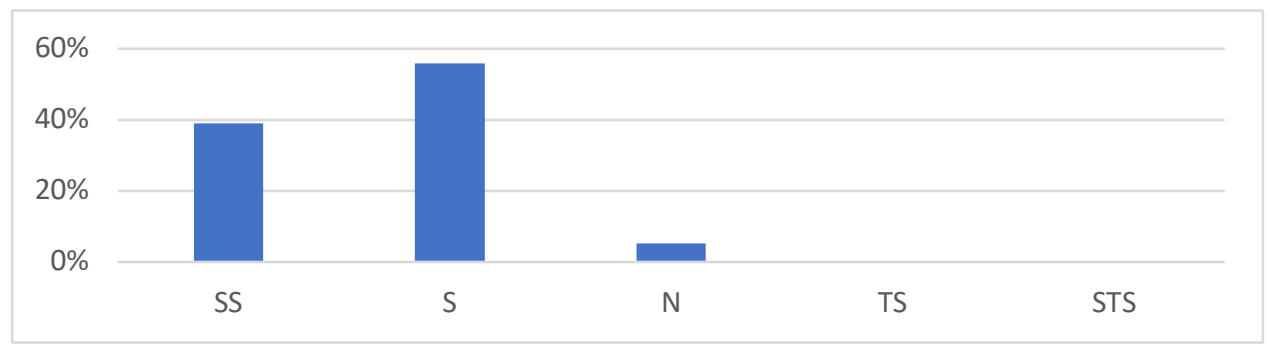

Gambar 3 Gambaran Jawaban Responden atas Persepsi Pelaku UMKM di kota Denpasar terhadap SAK EMKM

Sumber : Data diolah 2019

\begin{abstract}
Sosialisasi SAK EMKM pada pelaku UMKM di kota Denpasar

Berdasarkan hasil tabulasi yang didapat melalui kuesioner yang terdiri dari 4 item pernyataan dapat disimpulkan bahwa Sosialisasi SAK EMKM pada pelaku UMKM di kota Denpasar masih banyak responden
\end{abstract}

menjawab bahwa kurang adanya sosialsasi. Hal ini dibuktikan dengan jawaban kuesioner dari responden berjumlah 100 yang disajikan pada gambar 4 dalam bentuk persentase yaitu; jawaban sangat setuju (SS) sebanyak 6\%, Setuju (S) 35\%, netral (N) sebanyak 42\%, tidak setuju (TS) sebanyak 17\%. 


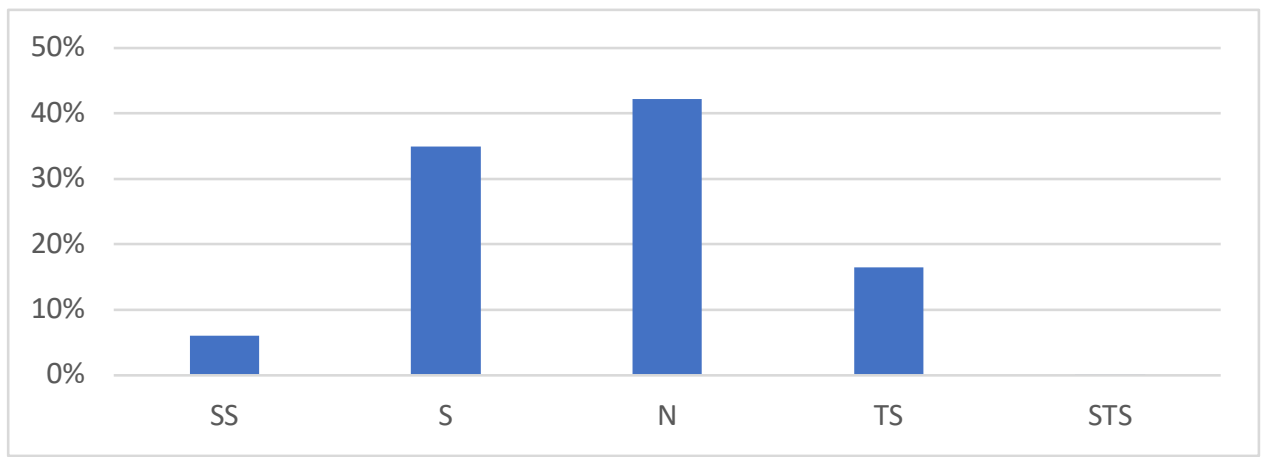

Gambar 4 Gambaran Jawaban Responden atas Sosialisasi SAK EMKM pada pelaku UMKM di kota Denpasar

Sumber : Data diolah 2019

\section{Pengaruh Persepsi Pelaku UMKM terhadap Penerapan SAK EMKM di kota Denpasar}

Hasil pengujian pada tabel 4.3 menunjukan signifikansi sebesar 0.164 lebih besar dari $\alpha=$ $(0,05)$ dapat diartikan persepsi pelaku usaha mikro, kecil dan menengah tidak berpengaruh terhadap penerapan SAK EMKM. Berdasarkan hal tersebut maka hipotesis pertama ditolak atau tidak didukung. Menurut peneliti dari hasil observasi para pelaku UMKM memang sudah memiliki persepsi yang baik sesuai pada gambar 2 tentang Gambaran Jawaban Responden atas Persepsi Pelaku UMKM di kota Denpasar terhadap SAK EMKM terhadap pentingnya penyusunan laporan keuangan namun data pada sosialisasi SAK EMKM pada gambar 3 tentang Gambaran Jawaban Responden atas Sosialisasi SAK EMKM pada pelaku UMKM di kota Denpasar menunjukan bahwa para pelaku UMKM sebagian besar belum merasa mendapatkan sosialisasi mengenai SAK EMKM sehingga walaupun pelaku UMKM di kota Denpasar memiliki persepsi yang baik mengenai pentingnya laporan keuangan yang memiliki standar namun SAK EMKM yang belum tersosialisasi menyebabkan hal tersebut menjadi tidak berpengaruh.

\section{Pengaruh Sosialisasi SAK EMKM terhadap Penerapan SAK EMKM di kota Denpasar} Hasil pengujian pada tabel 4.3 menunjukan signifikansi sebesar 0.000 lebih kecil dari $\alpha=$ $(0,05)$ dapat diartikan Sosialisasi Sak EMKM berpengaruh terhadap Penerapan SAK EMKM. Berdasarkan hal tersebut maka hipotesis kedua diterima atau didukung. Hal tersebut dapat dijelaskan hubungannya bahwa semakin tinggi sosialisasi SAK EMKM akan meningkatkan penerapan SAK EMKM di kota Denpasar. Menurut Shonhadji dan Djuwito (2017) menyatakan bahwa sosialisasi SAK EMKM sangat mendukung pelaku UMKM memahami bagaimana cara penggunaan dan keuntungan menggunakan SAK EMKM sehingga menurut peneliti berdasarkan hasil yang didapat akan meningkatkan penerapan SAK EMKM di kota Denpasar.

Tabel 1 Uji Hipotesis

\begin{tabular}{lcc}
\hline \multicolumn{1}{c}{ Variabel } & B & P value \\
\hline Persepsi Pelaku Usaha Mikro, Kecil Dan & 0,127 & 0,164 \\
Menengah (X1)-> Penerapan SAK & & \\
EMKM (Y) & 0,454 & 0,000 \\
\hline $\begin{array}{l}\text { Sosialisasi Sak EMKM (X2) )-> } \\
\text { Penerapan SAK EMKM (Y) }\end{array}$ & & \\
\hline \multicolumn{1}{c}{ Sumber : Data diolah 2019 }
\end{tabular}

\section{SIMPULAN DAN SARAN}

Berikut adalah kesimpulan yang dapat peneliti rangkum adalah. 1) Persepsi Pelaku UMKM tidak berpengaruh terhadap Penerapan SAK EMKM di kota Denpasar; 2) Sosialisasi
SAK EMKM berpengaruh positif terhadap Penerapan SAK EMKM di kota Denpasar

Beberapa Saran yang dapat peneliti rangkum adalah sebagai berikut; 1) Pada penelitian ini memiliki nilai $\mathrm{R}$ Square yang kecil yaitu 0,230 . Untuk penelitian selanjutnya 
disarankan memperbanyak sampel dan menggunakan wilayah yang lebih luas serta menambahkan beberapa variabel yang ada sehingga hasil penelitian bisa lebih dapat digeneralisasi, 2) Persepsi pelaku UMKM tidak berpengaruh terhadap penerapan SAK EMKM di kota Denpasar, namun beberapa peneliti di lokasi berbeda menyatakan bahwa Persepsi pelaku UMKM berpengaruh terhadap penerapan SAK EMKM. Untuk peneliti selanjutnya pertimbangkan menggunakan variabel moderasi atau variabel kontrol untuk menjelaskan perbedaan hasil ini.

\section{Daftar Pustaka}

Badan Pusat Statistik Bali, (2019). Statistik Indonesia Tahun 2019. Bali : Badan Pusat Statistik

Badria, N., \& Diana, N. (2018). Persepsi Pelaku Umkm Dan Sosialisasi Sak Emkm Terhadap Diberlakukannya Laporan Keuangan Yang Berbasis Sak Emkm . E Jurnal Ilmiah Riset Akuntansi , 55-66.

Hidayat, F. (2017, 4 20). Laporan Keuangan Masih Amburadul, Umkm Sulit Berkembang. (Warta Ekonomi) Retrieved 3 8, 2019, From Www.Wartaekonomi.Co.Id: Https://Www.Wartaekonomi.Co.Id/Rea d138494/Laporan-Keuangan-MasihAmburadul-Umkm-SulitBerkembang.Html

Iai. (2009). Standar Akuntansi Keuangan Entitas Tanpa Akuntabilitas Publik. Jakarta: Dewan Standar Akuntansi Keuangan

Iai. (2016). Standar Akuntansi Keuangan Entitas Mikro, Kecil Dan Menengah. Jakarta: Dewan Standar Akuntansi Keuangan

Janrosl, V. S. (2018). Analisis Persepsi Pelaku Umkm Dan Sosialisasi Sak Emkm Terhadap Diberlakukannya Laporan Keuangan Yang Berbasis Sak Emkm . Jurnal Politeknik Caltex Riau, 97-105.

Lubis, A. I. (2009). Akuntansi Keperilakuan. Jakarta: Salemba Empat.

Peraturan Menteri Keuangan Nomor 76/Pmk.05/2008 Tentang Pedoman Akuntansi Dan Pelaporan Keuangan Badan Layanan Umum
Salmiah, N., Nanda, S. T., \& Adino, I. (2018). Pemahaman Pelaku Umkm Terhadap Sak Emkm : Survey Pada Umkm Yang Terdaftar Di Dinas Koperasi Dan Ukm Kota Pekanbaru. Akuntansi Dewantara, Ii, 194-204.

Shonhadji, N., A, L. A., \& Djuwito, D. (2017). Penerapan Penyusunan Laporan Keuangan Pada Usaha Kecil Menengah Berdasarkan Sak Emkm Di Surabaya. Prosiding Seminar Nasional Pengabdian Masyarakat, 10-31.

Suadnyana, I. W. (2018, 12 6). Ini Alasan Bali Maju Pesat. Retrieved 3 8, 2019, From Bali.Tribunnews.Com:

Http://Bali.Tribunnews.Com/2018/12/0

6/Ini-Alasan-Umkm-Bali-Maju-Pesat

Undang-Undang $\mathrm{Ri}$ Tentang Usahamikro Kecil Menengah Nomor 20 Pasal 6 Tahun 2008 Pada Bab 1 Pasal 1 